discussed $\gamma$-globulin-levels in Jamaicans; he found no racial differences, but levels were higher in those with chronic infections than in the healthy. R. A. Webb (Barbados) analysed 330 first admissions to the Barbados Mental Hospital, in which records of mental ill-health for the whole island have been kept for many years. Heredity was revealed as a more important etiological factor than environment. K. L. Standard (Barbados) presented an analysis of child mortality in Barbados, reporting a marked reduction in infant mortality over the past six years. Miss $G$. Shaw, L. S. Grant and A. A. Peat (Jamaica) gave an account of the statistics of communicable disease in Jamaica up to 1956. K. H. Uttley (Antigua) discussed mortality from tuberculosis in the negro population of Antigua over the past 100 years. B. Weinstein (British Guiana) reported a survey of diabetes among residents on the sugar estates of British Guiana. He found an overall incidence of 2.04 per cent and discussed etiological factors. $J$. Parker-Williams (Univ. Coll., West Indies) described a survey of abnormal hæmoglobin in Barbados, with special reference to the sickling gene. He compared Barbados with Jamaica in this respect, and discussed genetical implications. R. J. Gourlay (Univ. Coll., West Indies) described the incidence of certain worm infestations in Jamaica. Miss A. Walters and Mrs. G. Jordan (Barbados), two public health nurses in Barbados, presented a most interesting time-study of the work of public health nurses at three health centres in Barbados, showing that more time was spent on maintenance and records than on the treat. ment and care of patients. H. M. Beadnell (British Guiana) recounted eight years experience with injuries and workmen's compensation in the sugar estates of British Guiana. D. O. Gore (Univ. Coll., West Indies) gave a clinical and pathological account of the portal hypertension produced by 'veno-occlusive disease', and reported on six patients treated by establishing porto-caval shunts. F. F. Laband (Trinidad) gave an account, illustrated with colour slides, of four years experience of oral surgery in the San Fernando General Hospital, Trinidad. A. G. Leacock and R. K. Rowley (Barbados) reported the results of repairing inguinal hernias by the 'nylon darn' technique. J. A. B. Jones (Univ. Coll., West Indies) discussed some anatomical and pathological abnormalities of the elimentary tract as seen in Jamaica. Winston Adams (British Guiana) gave an account of the control of two malaria outbreaks in the interior of British Guiana, discussed the difficulties of control of Anopheles darlingi, the local malaria vector, and mentioned the programme of chloroquinized salt prophylaxis now in operation in this area. E. L. S. Robertson (Trinidad) showed a film demonstrating the surgical trestment of filaria lymphœdema.

Excellent arrangements were made for the meeting by Dr. Maurice Byer, director of Medical Services, Barbados, and his staff.

\title{
HISTORY OF SCIENCES IN ANCIENT AND MEDIEVAL INDIA
}

\begin{abstract}
A SYMPOSIUM on the "History of Sciences in Ancient and Medieval India" was held during August 4-5 at the Bose Institute, Calcutta, under the auspices of the National Institute of Sciences of India. The symposium was inaugurated by Dr. D. M. Bose, director of the Bose Institute. In his opening remarks, Dr. A. C. Ukil, convener of the symposium, referred to the importance the study of the history of sciences in India had assumed during recent years and the problems which the workers in the field have to face, especially in connexion with the source materials. The discrepancy of knowledge regarding chronology, he observed, constituted a serious difficulty which should engage the attention of the research workers in the subject. Regarding the investigations already made, which he termed secondary sources, the attitude taken in the past and points of view expressed required in many instances to be re-examined and re-evaluated.
\end{abstract}

Thirty-five papers were received for the symposium of which twenty-three were read and discussed. In his paper on the social and international relations in the development of science, Dr. R. C. Majumdar pointed out that there is direct evidence to show that scholars from India visited Western countries and taught the people there medical science, astrology, astronomy, algebra and arithmetic as known to India and also indirect evidence of intermational exchange of scientific knowledge between India and foreign countries. European scholars have generally held that in scientific matters it was India that must have borrowed from Western countries. But with the advance in knowledge of history, he observed, it was difficult to subscribe to this viow of one-way traffic.
This observation was further substantiated in the paper by Sri S. N. Sen, who furnished archæological and epigraphic examples and also case-histories such as the transmission of the knowledge of the decimal place-value notation, and some medical and astronomical ideas.

In biology, health and medicine, Dr. N. H. Keswani discussed the concepts of generation, reproduction, evolution and human development as found in the writings of Indian scholars of the ancient and medieval period. He noted that the results of their observations, unaided by microscopes and modern appliances, approached in accuracy those of modern work, especially in the field of embryology. Zoological knowledge in the works of $K_{\dot{a}}$ lidasa formed the subject of two papers by Sri C. S. Gupta and Sri B. Rama Rao, while Dr. S. S. Misra gave a review of the development of medical sciences in India.

On Indian chemistry, Dr. B. V. Subbarayappa's paper dealing with Indian atomism showed independent development of the atomic concept of matter in the Hindu, Buddhist and Jaina literature and the difference between the Indian ideas and those propounded by the Greek acholars headed by Democritus and Leucippus. Dr. S. P. Raychaudhuri and Dr. A. K. Bhattacharyya dealt with the agricultural practices and soil science in ancient India.

The geographical ideas of the Hindus were presented by Dr. S. M. Ali. Besides these were the discussions on the development of mathematical series in India after Bhaskara II, Bhaskara's works on differential and integral calculus, science and society in the Arthasastra and the Ramayana, and the general scientific contents in the Vedic literature. S. N. S. 